constant of $1.544 \mathrm{mT}$. By the use of the general TRIPLE resonance technique, ${ }^{[7]}$ the values of 1.544 and $0.051 \mathrm{mT}$ are found to have the same sign, which is opposite to that of 0.117 and $0.065 \mathrm{mT}$.

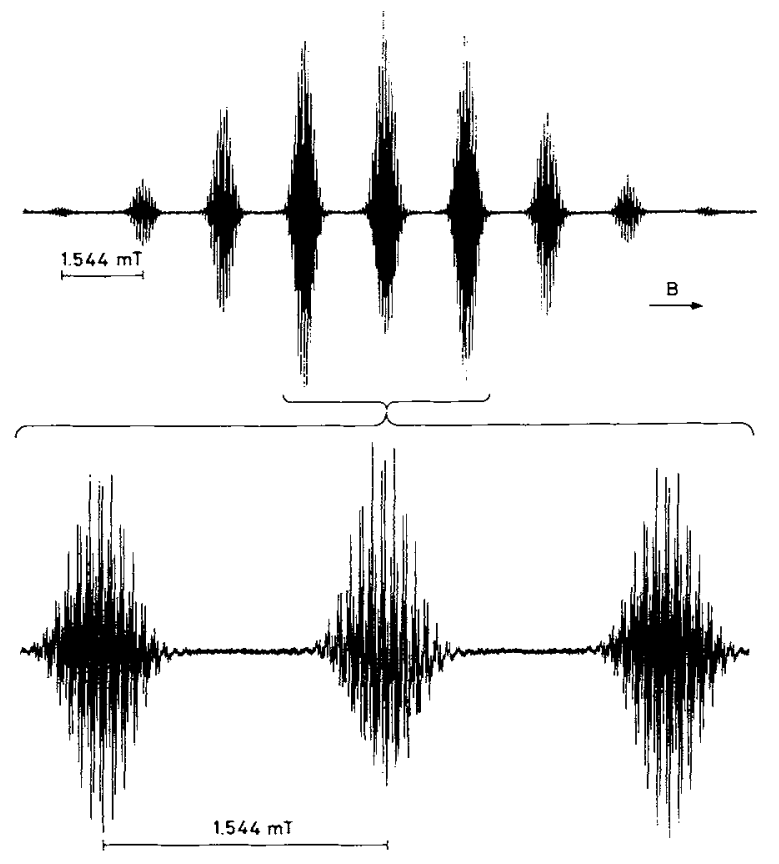

Fig. 2. ESR spectrum of the radical cation 7 generated from 1 or $3\left(\mathrm{CH}_{2} \mathrm{Cl}_{2}\right.$, $-40^{\circ} \mathrm{C}$ ). Top: complete spectrum. Bottom: part of the spectrum including the three central groups of lines at an expanded magnetic field scale.

An identical ESR spectrum is observed for the diene 3 subjected to the same treatment; in line with the lower oxidation potential, the appearance voltage in the electrolysis is substantially lower than for 1 . The results of the ESR studies are thus fully consistent with the postulated cycloreversion $5 \rightarrow 7$, so that the structure of the radical cation should be properly described by formula 7 .

Assignment of the large coupling constant (1.544 $\mathrm{mT})$ to the eight equivalent $\beta$ protons, i.e., to those that are separated by one $\mathrm{C}-\mathrm{C}$ bond from the $\pi$ system of 7 , is straightforward, considering the $D_{2 h}$ symmetry. The coupling constants, $a_{H^{3}}$, of $\beta$ protons arise from hyperconjugation and obey the relationship ${ }^{|8|} a_{\mathrm{H}^{4}}=\mathrm{B} \cdot \rho^{\pi} \cdot \cos ^{2} \theta$, where $\rho^{\pi}$ is the spin population at the adjacent $\pi$ center and $\theta$ stands for the dihedral angle between the $2 \mathrm{p}$, axis at this center and the $\mathrm{C}-\mathrm{H}^{\beta}$ bond. Since the total $\pi$-spin population in 7 is evenly distributed among the four $\pi$ centers, $\rho^{\pi}$ amounts to 0.25 . Taking $+6 \mathrm{mT}$ as the proportionality factor $\mathrm{B}$ appropriate for radical cations and setting $\theta \approx 10^{\circ}$ on the basis of structural data for $3,^{(9)}$ one obtains $a_{\mathrm{H}^{13}}=+1.5 \mathrm{mT}$. According to the evidence from TRIPLE, the positive sign thus predicted for $1.544 \mathrm{mT}$ also holds for $0.051 \mathrm{mT}$, whence 0.117 and $0.065 \mathrm{mT}$ must be negative. Assignments of the three last-mentioned coupling constants to the three sets of four equivalent $\gamma$ protons in specific positions of 7 are hardly feasible without further information.

The colored radical cation $\left(\lambda_{1 \mathrm{n}, \mathrm{x}} \approx 610 \mathrm{~nm}\right)$ generated under similar conditions from [2.2.1.1]pagodane $\mathbf{2}$ is also rather persistent; however, it decays faster than 7 . By ana$\operatorname{logy}$ to 7 , its structure should be described by formula 8 . The ESR spectrum $(g=2.0040 \pm 0.0001)$ reflects the lower $C_{2 r}$. symmetry of 8 by exhibiting two large coupling con- stants, $1.76 \pm 0.01$ and $0.96 \pm 0.01 \mathrm{mT}$, each due to a set of four equivalent $\beta$ protons. The hyperfine splittings of the sixteen $\gamma$ protons belonging to six different sets are not resolved in the ESR spectrum; they do not exceed $0.1 \mathrm{mT}$, as indicated by the ENDOR spectrum. ${ }^{[(t)]}$

The persistence of the radical cations $7 / 8$ is closely connected with their polycyclic skeletons. Under a variety of oxidation conditions, it was not possible, by ESR spectroscopy, to detect radical cations generated from the "molecular moieties" of $1 / 3(8 / 9$ in Ref. [2]). The opening of the four-membered ring, which occurs upon formation of the dications $11 / 12$ from the pagodanes $1 / 2$, presumably also occurs in 5/6 (ECE) but not in 9/10 (EEC). Owing to the small exothermicity of the opening $1 \rightarrow 3\left(\Delta \Delta H_{\mathrm{f}}^{\mathrm{o}}=-2.4\right.$ $\mathrm{kcal} / \mathrm{mol}),{ }^{[1]}$ and presumably also of $5 \rightarrow 7$, and owing to the rigidity of the [1.1.1.1]pagodane 1 , there is a good chance that 5 might be identified directly at low temperature ${ }^{[12]}$ and that 5 and 7 as well as 9 and 11 might be differentiated in the gas-phase oxidation ("charge stripping"). ${ }^{[13]}$

Received: January 19, 1987 [Z 2055 IE] German version: Angew. Chem. 99 (1987) 488

[1] G. K. S. Prakash, V. V. Krishnamurthy, R. Herges, R. Bau, H. Yuan, G. A. Olah, W.-D. Fessner, H. Prinzbach, J. Am. Chem. Soc. 108 (1986) 836.

[2] W.-D. Fessner, Bulusu A. R. C. Murty, H. Prinzbach, Angew. Chem. 99 (1987) 482; Angew. Chem. Int. Ed. Engl. 26 (1987) 451.

[3] The $\mathrm{He}(\mathrm{l} \alpha) \mathrm{PE}$ spectrum of 1 (recording temperature ca. $100^{\circ} \mathrm{C}$ ) exhibits an initial, broad band with a maximum at $I^{\prime \prime} \approx 8.2$ to $8.3 \mathrm{eV}$, followed by a band system with little structure. The point at which the first band emerges above the noise level is at 7.7 to $7.8 \mathrm{eV}$, which allows an upper limit for the adiabatic ionization energy 1 ; to be determined ( $E$. Heilbronner, J. Lecoultre, private communication).

[4] J. Heinze, Angew. Chem. 96 (1984) 823; Angew. Chem. Int. Ed Engl. 23 (1984) 831

[5] M. Dietrich, J. Mortensen, J. Heinze. Angen'. Chem. 97 (1985) 502: Angew. Chem. Int. Ed. Engl. 24 (1985) 508.

[6] H. Ohya-Nishiguchi, Bull. Chem. Soc. Jpn. 52 (1979) 2064.

[7] Review: H. Kurreck, B. Kirste, W. Lubitz, Angen'. Chem. 96 (1984) 171; Angew. Chem. Int. Ed. Engl. 23 (1984) 173.

[8] C. Heller, H. M. McConne[1, J. Chem. Phys. 32 (1960) 1535

[9] W.-D. Fessner, H. Prinzbach, G. Rihs, Tetrahedron Lett. 24 (1983) 5857.

[10] According to the relative intensities of the ENDOR signals, an appreciable part of the $16 \%$ protons must have a coupling constant close to $0.025 \mathrm{mT}$.

[11] P. R. Spurr, Bulusu A. R. C. Murty, W.-D. Fessner, H. Fritz, H. Prinzbach, Angew' Chem 99 (1987) 486; Angew. Chem. Int. Ed. Engl. 26 (1987) 455

[12] Cf. E. Haselbach, T. Bally, Z. Lanyiova, P. Baertschi, Helt. Chim. Acla 62 (1979) 583: H. D. Roth, M. L. M. Schilling, T. Mukai, T. Miyashi, Tetrahedron Lett. 24 (1983) 5815.

[13] W. Koch, F. Maquin, D. Stahl, H. Schwarz, Chimia 39 (1985) 376

\section{Enzyme-Catalyzed Cyanohydrin Synthesis in Organic Solvents}

\section{By Franz Effenberger, ${ }^{*}$ Thomas Ziegler, and Siegfried Förster}

Pfeil et al. have described the enantioselective addition of hydrogen cyanide 2 to benzaldehyde and numerous other aldehydes 1 in the presence of the enzyme mandelo nitrile lyase (" $(R)$-oxynitrilase") to give optically active $(R)$-cyanohydrins $3 .^{[l]}$ However, in the aqueous and aqueous alcoholic systems exclusively used so far, the chemical reaction, leading to the formation of racemates, occurs in

[*] Prof. Dr. F. Effenberger, Dr. T. Ziegler, Dr. S. Förster Institut für Organische Chemie der Universität Pfaffenwaldring 55, D-7000 Stuttgart 80 (FRG) 
addition to the enzyme-catalyzed reaction, so that only moderate optical yields are often obtained in this reaction. ${ }^{[|c|}$<smiles>[R]C(=O)[CH-]NCC</smiles>

The ready accessibility ${ }^{[2]}$ of mandelonitrile lyase (E.C. 4.1.2.10) from bitter almonds (Prunus amygdalus) and the great importance of optically active cyanohydrins for the preparation of optically active amino alcohols, ${ }^{11 \mathrm{cl}} \alpha$-hydroxy carboxylic acids, pyrethroid insecticides, ${ }^{[3: t]}$ imidazoles, and heterocycles, ${ }^{[3 h]}$ prompted us to investigate this reaction in more detail. Our goal was the preparative synthesis of cyanohydrins having the highest possible enantiomeric purity.

Variation of the reaction conditions ( $\mathrm{pH}$ value, temperature, concentration) in water/ethanol led to no appreciable improvements. "I The use of organic solvents that are not miscible with water but in which the enzyme-catalyzed reaction can take place, ${ }^{[4]}$ however, resulted in suppression of the chemical reaction to a significant extent, whereas the enzymatic formation of cyanohydrin was only slightly slower (Fig. 1). The enantiomeric purity of the cyanohydrins is thereby considerably increased.

Of the organic solvents we tested, ethyl acetate proved to be the most suitable; the enantiomeric purity thereby achieved is higher than in $\mathrm{H}_{2} \mathrm{O} / \mathrm{EtOH}$. The enzyme can be bound to a fixed support and consequently reisolated and used again. Of the supports tested, ECTEOLA cellulose, DEAE cellulose, glass beads, and cellulose, cellulose proved to be the best.

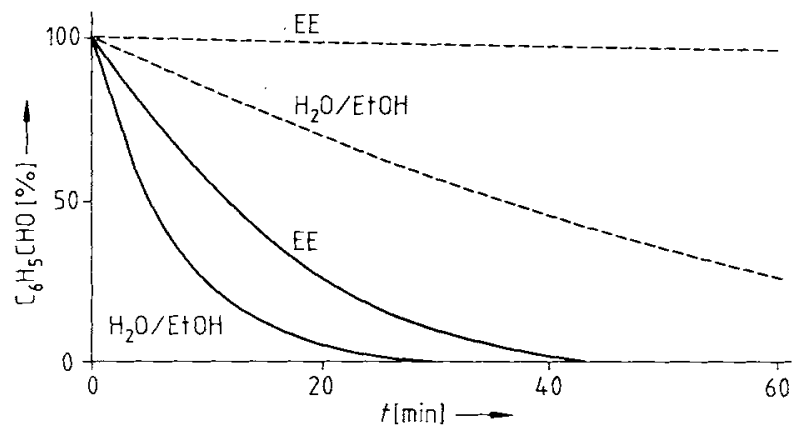

Fig. 1. Rate of the chemical (- -) and enzymatic additions (-) of HCN to benzaldehyde (initial concentration $5 \times 10^{-3} \mathrm{M}$ ) in $\mathrm{H}_{2} \mathrm{O} / \mathrm{EtOH}$ and in ethy! acetate $(E E) /$ cellulose

In the earlier investigations, ${ }^{[1]}$ the optical yields were solely determined from the optical rotation of the products obtained. However, because only mandelonitrile was available in pure form, only the reaction of benzaldehyde with hydrogen cyanide allowed a statement to be made about the optical purity of the product; in general, precise statements as to the optical purity of a compound cannot be made from the optical rotation values. Furthermore, cyanohydrins undergo ready isomerization by means of the equilibrium reaction. We therefore converted the cyanohydrins so obtained into diastereomeric esters by reaction with $(R)$ - $\alpha$-methoxy- $\alpha$-trifluoromethylphenylacetoyl chloride $[R(+) \text {-MTPA chloride }]^{[s]}$ and determined their optical purity by gas chromatography. The results of the enzymatic cyanohydrin syntheses carried out by us, on the one hand, in $\mathrm{H}_{2} \mathrm{O} / \mathrm{EtOH}$ (according to Ref. [1]) and, on the other hand, in ethyl acetate, are compared in Table 1.

Table 1. Enzymatic formation of cyanohydrins 3 in $\mathrm{H}_{2} \mathrm{O} / \mathrm{EtOH}$ (see Experi mental Procedure $A$ ) and in ethyl acetate (EE)/cellulose (see Experimental Procedure B).

\begin{tabular}{|c|c|c|c|c|c|c|}
\hline \multirow[b]{2}{*}{$\begin{array}{l}\text { Aldehyde } \\
1\end{array}$} & \multicolumn{3}{|c|}{3 in $\mathrm{H}_{2} \mathrm{O} / \mathrm{EtOH}$} & \multicolumn{3}{|c|}{3 in $\mathrm{EE} /$ cellulose } \\
\hline & $\begin{array}{l}\text { Reaction } \\
\text { time [h] }\end{array}$ & $\begin{array}{l}\text { Yield } \\
{[\%]}\end{array}$ & $\begin{array}{l}\text { ee }[\mathrm{a}] \\
{[\%]}\end{array}$ & $\begin{array}{l}\text { Reaction } \\
\text { time [h] }\end{array}$ & $\begin{array}{l}\text { Yield } \\
{\left[{ }^{\prime} \text { in] }\right.}\end{array}$ & 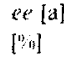 \\
\hline Benzaldehyde & 1 & 99 & 86 & 2.5 & 95 & 99 \\
\hline $\begin{array}{l}\text { 3-Phenoxy- } \\
\text { benzaldehyde }\end{array}$ & 5 & 99 & 10.5 & 192 & 99 & 98 \\
\hline Furfural & 2 & 86 & 69 & 4 & 88 & 98.5 \\
\hline $\begin{array}{l}\text { Nicotine- } \\
\text { aldehyde }\end{array}$ & 2.5 & 78 & 6.7 & 4.5 & 89 & 14 \\
\hline Crotonaldehyde & 1.5 & 68 & 76 & 3 & 68 & 97 \\
\hline $\begin{array}{l}\text { Phenyl- } \\
\text { acetaldehyde }\end{array}$ & 4 & 82 & 27 & 4.5 & 95 & 40 \\
\hline $\begin{array}{l}\text { 3-Methylthio- } \\
\text { propionaldehyde }\end{array}$ & 3 & 87 & 60 & 6.5 & 97 & 80 \\
\hline $\begin{array}{l}\text { Pival- } \\
\text { aldehyde }\end{array}$ & 2.5 & 56 & 45 & 4.5 & 78 & 73 \\
\hline Butyraldehyde & 2 & 75 & 69 & 4.5 & 75 & 96 \\
\hline
\end{tabular}

[a] As $(R)-(+)$-MTPA derivatives

The comparison shows that, although the synthesis in ethyl acetate requires longer reaction times, the enantiomeric purity is appreciably better than it is for the reaction in $\mathrm{EtOH} / \mathrm{H}_{2} \mathrm{O}$.

More recent investigations into the preparation of $O$ acylated cyanohydrins by reaction of optically active cyanohydrins with dipeptide catalysts ${ }^{\left[{ }^{[}\right]}$or by enzymatic ester cleavage ${ }^{171}$ were less satisfactory with respect to optical and preparative yields.

\section{Experimental Procedure}

A) Mandelonitrile lyase solution $\left(150 \mu \mathrm{L}, 700\right.$ Units $/ \mathrm{mL}, A_{\text {,p }}=65$ Units $/ \mathrm{mg}$, in $0.02 \mathrm{M}$ acetate buffer, $\mathrm{pH} 5.4$ ) was added by pipette to $10 \mathrm{~mL}$ of $0.05 \mathrm{M}$

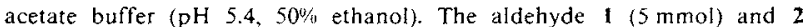
$(250 \mu \mathrm{L}, 6.5 \mathrm{mmol})$ were then added. The mixture was shaken until a clear solution had formed, allowed to stand for the allotted length of time (Table 1), and extracted with chloroform. The extract was dried and the organic phase was removed in a rotary evaporator.

B) The support ( $2 \mathrm{~g}$, AVICEL cellulose) was allowed to swell in $20 \mathrm{~mL}$ of $0.01 \mathrm{M}$ acetate buffer ( $\mathrm{pH} 5.4$ ) for $1-2 \mathrm{~h}$. The support was then filtered off pressed, and transferred to a one-necked flask, and $150 \mu \mathrm{L}$ of mandeionitrile lyase solution (see A) was added followed by $20 \mathrm{~mL}$ of ethyl acetate (saturated with $0.01 \mathrm{M}$ acetate buffer, $\mathrm{pH} 5.4), 5.0 \mathrm{mmol}$ of $\mathrm{I}$ and $250 \mu \mathrm{L}$ $(6.5 \mathrm{mmol})$ of 2 . The mixture was allowed to stand at room temperature for the allotted length of time (Table 1) and filtered. The filter cake was pressed and washed with ethyl acetate. The combined solutions were dried and the organic phase was removed in a rotary evaporator.

For example, $0.53 \mathrm{~g}$ of benzaldehyde $1, R=\mathrm{Ph}$, gave, according to $\mathrm{A}$ in $\mathrm{i}-\mathrm{h}$ reaction time, $0.66 \mathrm{~g}(99 \%)$ of benzaldehydecyanohydrin $3, \mathrm{R}=\mathrm{Ph},[\alpha]_{i}^{2}=$ $+45^{\circ}\left(c=5, \mathrm{CHCl}_{3}\right), e e=86 \%$. According to $\mathrm{B}$ in $2.5 \mathrm{~h}, 0.63 \mathrm{~g}\left(95^{\circ} \%\right)$ of 3 , $\mathrm{R}=\mathrm{Ph},[\alpha]_{i}^{30}=+49^{\circ}\left(c=5, \mathrm{CHCl}_{3}\right), e e=99.3 \%$, was obtained.

Received: January 26, 1987 : supplemented: February 16, 1987 [Z 2068 ]E] German version: Angew. Chem. 99 (1987) 491

[1] a) W. Becker, U. Benthin, E. Eschenhof, E. Pfeil, Biochem. Z. 337 (1963) 156; b) W. Becker, E. Pfeil, ibid. 346 (1966) 301; c) W. Becker, H. Freund, E. Pfeil, Angew. Chem. 77 (1965) 1139; Angew. Chem. Int. Ed. Engl. 4 (1965) 1079; E. Pfeil, W. Becker, DBP 1300111 (1969): Chem. Abstr. 72 (1970) P $3061 \mathrm{t}$.

[2] E. Hochuli, Helv. Chim. Acta 66 (1983) 489. 
[3] a) T. Matsuo, T. Nishioka, M. Hirano, Y. Suzuki, K. Tsushima, N. Itaya, H. Yoshioka, Pestic. Sci. 1980. 202; b) D. G. Neilson, D. A. V. Peters, L. H. Roach, J. Chem. Soc, 1962, 2272.

[4] a) P. L. Luisi, Angew' Chem. 97 (1985) 449: Angew' Chem. Int. Ed. Engl. 24 (1985) 439; b) A. M. Ktibanov, CHEMTECH 1986, 354.

[5] a) J. A. Dale, D. L. Dull, H. S. Mosher, J. Org. Chem. 34 (1969) 2534 ; b) J. D. Elliot, V. M. F. Choi, W. S. Johnson, ibid. 48 (1983) 2294

[6] a) S. Asada, Y. Kobayashi, S. Inoue, Makromol. Chem. 186 (1985) 1755: b) W. R. Jackson, Brit. Pat. 2143823 (1985), ICI Australian Ltd.; Chem. Abstr. 104 (1986) $68624 \mathrm{c}$.

[7] H. Hirohara, S. Mitsuda, E. Ando, R. Komaki, Stud. Org. Chem. (Amsterdam) Vol. 22 (1985) p. 119; Chem. Abstr. 104 (1986) 67464 p.

\section{Quino|7,8-hlquinoline, a New Type of "Proton Sponge"**}

\section{By Michael A. Zirnstein and Heinz A. Staab*}

So far, "proton sponges" have been defined as bis(dialkylamino)arenes whose dialkylamino groups are in close spatial proximity. ${ }^{[1]}$ The unusual basicity of these compounds is ascribed to the destabilizing overlap of the lone electron pairs on the nitrogen atoms, to the formation of especially strong hydrogen bonds in the monoprotonated diamines, and to the hydrophobic shielding of these hydrogen bonds. In order to differentiate and assess the relative importance of these factors, we were interested in quino[7,8-h]quinoline 1 , whose nitrogen atoms exhibit a mutual orientation similar to that in 1,8-bis(dimethylamino)naphthalene 2 ("proton sponge"). In contrast to $\mathbf{2}$, however, 1 lacks the hydrophobic shielding of the hydrogen bonds of its monoprotonated derivative. This shielding is considered to be responsible for the low rates of proton transfer, which make the "proton sponges" reported so far unsuitable as auxiliary bases in chemical reactions.

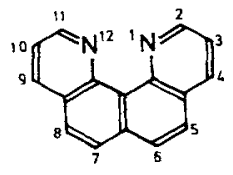

1

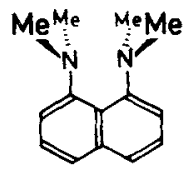

2
The synthesis and properties of 1 have been reported by several groups. ${ }^{[2]}$ In all cases, however, these claims proved to be incorrect, ${ }^{[3]}$ so that, to the best of our knowledge, 1 was unknown until now.

Our synthesis of 1 started from tetramethyl $2,2^{\prime}-(1,8$ naphthylenediimino)difumarate 3 , which was obtained, by a modified procedure of Honda et al., ${ }^{[4]}$ from 1,8-diaminonaphthalene and dimethyl acetylenedicarboxylate (molar ratio $1: 2$, methanol; m.p. $=142-143^{\circ} \mathrm{C} ; 71 \%$ yield). ${ }^{[5]}$ Thermal cyclization of 3 (diphenyl ether, $240^{\circ} \mathrm{C}$ ) gave dimethyl 4,9-dioxo-1,4,9,12-tetrahydroquino[7,8-h]quinoline2,11 -dicarboxylate 4 (m.p. $=276-278^{\circ} \mathrm{C} ; 64 \%$ yield). ${ }^{15.6]}$

Alkaline hydrolysis of $\mathbf{4}$ afforded the corresponding dicarboxylic acid 5 (m.p. $=314-315^{\circ} \mathrm{C}$, dec.; 93\% yield), ${ }^{[5]}$ which underwent decarboxylation at 335 to $370^{\circ} \mathrm{C} / 10^{-5}$ torr in a sublimation apparatus to give quino[ $[7,8-h]$ quinoline-4,9-(1H,12H)-dione 6 (m.p. $=375-377^{\circ} \mathrm{C}$, dec.; 76\%

[*] Prof. Dr. H. A. Staab, Dipl.-Chem. M. A. Zirnstein Abteilung Organische Chemie,

Max-Planck-Institut für medizinische Forschung

Jahnstrasse 29, D-6900 Heidelberg (FRG)

[**] New "Proton Sponges," Part 4.-Part 3: [1c].

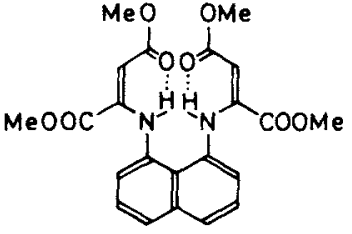

3

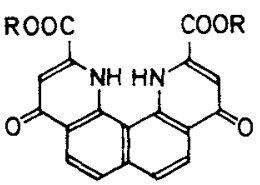

4: $R=M e, 5: R=H$ yield). ${ }^{[S]}$ Short heating of 6 at reflux with phosphoryl chloride gave 4,9-dichloroquino[7,8-h]quinoline 7 (m.p. $=234-$ $235^{\circ} \mathrm{C} ; 81 \%$ yield), ${ }^{[S]}$ which was converted into 1 (m.p. $\left.=196-197^{\circ} \mathrm{C}, 39 \%\right)^{[5]}$ by catalytic hydrogenation $(\mathrm{Pd} / \mathrm{C}$, glacial acetic acid, sodium acetate).

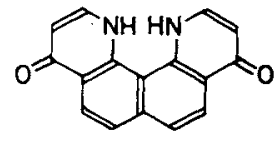

6

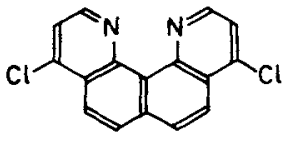

7
The compound thereby obtained gave the correct elemental analysis and spectroscopic data for the structure of 1. In the mass spectrum, besides $m / z 230\left(M^{\oplus}, 100 \%\right), 229$ $(25 \%)$, and $115\left(M^{2 \odot}, 13 \%\right)$, no other fragment ions with $I_{\mathrm{rel}}>5 \%$ appear. Comparison of the ${ }^{1} \mathrm{H}-\mathrm{NMR}$ spectrum $\left(\mathrm{CDCl}_{3}, 360 \mathrm{MHz}\right)$ with that of quinoline leads to the following assignments: $\delta=7.60$ (dd, $J=4.3 \mathrm{~Hz}, 8.1 \mathrm{~Hz}, 2 \mathrm{H}$; $3,10-\mathrm{H}), 7.98($ 's, $4 \mathrm{H} ; 5,8-\mathrm{H}$ and $6,7-\mathrm{H}), 8.32(\mathrm{dd}, J=1.9$ $\mathrm{Hz}, 8.1 \mathrm{~Hz}, 2 \mathrm{H} ; 4,9-\mathrm{H}), 9.43$ (dd, $J=1.9 \mathrm{~Hz}, 4.5 \mathrm{~Hz}, 2 \mathrm{H}$; 2,11-H).

Like other "proton sponges," 1 reacts with perchloric acid in excess to form only a monoperchlorate (colorless needles, m.p. $\left.=282-285^{\circ} \mathrm{C}\right){ }^{\left[{ }^{[S]}\right.}$ The structure 8 , containing a very strong $\mathrm{N} \cdots \mathrm{H} \cdots \mathrm{N}$ hydrogen bond, was established from the 'H-NMR spectrum, ${ }^{\text {[7] }}$ which exhibits a broadened singlet at $\delta=19.38$, the most strongly downfield-shifted proton resonance observed so far for an $\mathrm{N} \cdots \mathrm{H} \cdots \mathrm{N}$ hydrogen bond (in dimethyl sulfoxide (DMSO)). Analogously, the monoperchlorate 9 (m.p. $=317-318^{\circ} \mathrm{C}$, dec. . $^{[5]}$ is obtained from 7 . The hydrogen-bonded proton of 9 absorbs at $\delta=19.34$

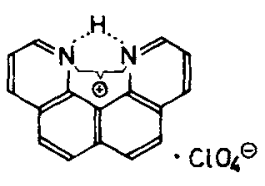

8

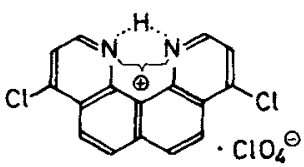

9
On the basis of transprotonation experiments of 1 with protonated 2 and of 2 with 8 , the $p K_{a}$ value of 1 was estimated to be 12.8 by ' $\mathrm{H}-\mathrm{NMR}$ spectroscopy $(500 \mathrm{MHz}$, $\left[D_{6}\right]$ DMSO). Accordingly, the basicity of 1 compared with quinoline ( $\left.\mathrm{p} K_{\mathrm{i}}=4.91\right)$ is increased by nearly eight orders of magnitude, which roughly corresponds to the increase of basicity of 2 compared with $N, N$-dimethylaniline. ${ }^{[1]}$ Whereas the hydrophobic shielding of the $\mathrm{N} \cdots \mathrm{H} \cdots \mathrm{N}$ hydrogen bond plays only a minor role in the basicity of "proton sponges," it has a great effect on the rate of proton transfer: the ' $H$-NMR spectra of mixtures of 1 and 8 in $\left[D_{6}\right]$ dimethyl sulfoxide at $30^{\circ} \mathrm{C}$ exhibit coalesced signals 